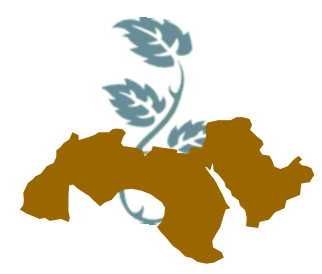

Arab Univ.

J. Agric. Sci., Ain Shams Univ., Cairo Special Issue, 26(2A), 909-922, 2018

\title{
EFFECT OF BARLEY ETIOLATED SPROUTING WITH SOME HAYS USING SALINE WATER ON THE NUTRITIONAL AND ECONOMICAL VALUE OF THE PRODUCT
}

\author{
Hassan $^{1}$, A.S.; U.A.A. EL-Behairy ${ }^{2}$; A.A. Bakr ${ }^{1}$ and M.M.F. Abdallah ${ }^{2}$ \\ 1- Regional Central for Food and Feed, Agric. Res., Center, Giza, Egypt \\ 2- Horticulture Dept., Fac. of Agric., Ain Shams Univ., Cairo, Egypt
}

Keywords: Barley grain, Etiolated sprout, Hay, Sprout fodder digestibility, Nutritional value, Fiber fraction

\section{ABSTRACT}

The study was designed to evaluate the effect of barley grain etiolated sprouts mixture with faba bean, Egyptian clover, wheat and rice hays to improve fodder value. Hays were used as media to etiolated sprouts of barley with three seeding densities (10, 20 and 30\% w: w). Growing conditions of the system can produce between 12.8 to $38.38 \mathrm{Kg}$ of fresh fodder and 3.18 to $9.10 \mathrm{Kg}$ of dry fodder in 4 days from one kilogram of dry barley grains. The dry fodder per unit seed volume (Kg/Kg grain) was decreased with increasing seed density. Since hays were decreased but the nutrient content of the fodder, especially protein was increased. Barley etiolated sprouts improved quality of hays fodder from faba bean, Egyptian clover, rice and wheat crop. Carbohydrate lipid, protein and total energy content were increased with increasing barley-seeding density while crude fiber was decreased. In vitro dry matter digestibility (IVDMD) was decreased with decreasing seed density especially with rice hays (39.92) and increased with increasing seeding density especially with faba bean hays (74.77). Fiber fraction (Neutral detergent fiber NDF, Acid detergent fiber ADF, Acid detergent lignin ADL), cellulose and lignin percentage were decreased with increasing seeding density of barley, Relative feed value (RFV) was increased with increasing seed density for barley grown on faba bean, Egyptian clover, rice and wheat hays.
The barley etiolated sprout production system obtained a good quality fresh forage in small area all year around and low cost estimated per ton DM; total digestible nutrients (TDN) and crude protein (CP) compared with hydroponic barely green sprouts. Therefore, the system can recommended as cheap energy (TDN) and protein (CP). In addition, the system saving agricultural lands and partially water consumption for strategy crop production as wheat and corn since its fodder products can produced and grown in small dark area during absence of natural forage.

\section{INTRODUCTION}

The main constrains for improving and developing animal production in Egypt is the reduction in local feedstuff resources. In semi-arid areas, nutritional stress is a major constraint to ruminant livestock production in dry season .Industrial investment and animal production suffer from different problems due to the requirements of human crops and competition with adequate animal feeding requirements. Thus, one-third of the world's total cultivated area is cultivated with crops used for animal feed. In this regard, efforts must be made, and new solutions sought to counter this competition (El-Deeba, Mona, et al 2009). Therefore, it is believed that inclusion of some agricultural byproducts to replace a part of diet for animals become an obligation [EI-Tahan et al 2003; Abdallah et al 2014 and Deraz, Hayam et al 2015]

In Egypt, rice and wheat hays reaches about 12.1 million tons. Few attempts were tried to improve quality of wheat and rice hay to be used as an animal feed, these include addition of ammonia (Mason and Owen, 1985) and growing grain with hay (Ibrahim et al 2001 and Abdallah et al 2014). 
Also, faba bean and Egyptian clover hays reaches about 2.5 million tons in Egypt. These residues are high in crude fiber and low in nitrogen, which affect the amount of animal diet nutrition and digestion. These attempts lead to getting rid of crop surplus by-products and providing feed with better quality without need to grow any crops that will use a cropping area. Using seed sprouts to improve nutritional value of these hays will lead to increase the rote of utilization in future (Sneath and Mclntosh, 2003; Mohammadi and Abdallah, 2007; Abdallah et al 2014 and Deraz, Hayam et al 2015).

The hydroponics green fodder is a well-known technique for high fodder yield, year round production and least water consumption [Tudor et al 2003; Al-Hashmi, 2008 and Al-Karaki, 2011]. This technology may be especially important in regions where forage production is limited [Mukhopad, 1994 and Buston, et al 2002], but there are some arguments about the technique to compensate the feed resources for animals (Rajendra et al 1998 and Tudor et al 2003].

Limited research has been conducted to determine the value of sprouted barely grains, however, Chung et al (1989) measured $9.4 \%$ decreased in dry matter of sprouted barely grains over 5 days, while Abdallah et al (2014) and Deraz, Hayam et al (2015) found $15 \%$ loss for 7 days.

On the other hand, sprouted barley grains on rice straw revealed significant improvement in $\mathrm{CP}$ and TDN g / kg body weight (Helal, 2012; Fazaeli et al 2012 and Abdallah et al 2014). Moreover, Deraz, Hayam, et al (2015) reported that, the fresh green feed barely sprout technique grown on rice straw medium obtained a good quality fresh forage in small area all year around and recommend as cheap sources of energy (TDN) and protein (CP) compared with hydroponic barely and corn silage.

No research has been conducted to determine the value of etiolated sprouted barely grains therefore this research was conducted to compare the economic production and nutritional value of etiolated sprouted barely grown in wheat, rice, faba bean and Egyptian clover hays media [using tap water or $\mathrm{NaCl}$ solution] compared with commercial feedstuff in Egypt (corn silage and alfalfa) in addition to hydroponic green barely sprouts and sprouted green barley on rice straw.

\section{MATERIALS AND METHODS}

The present work was carried out during the winter seasons 2015 and 2016 in Horticulture department, Fac. of Agric. Ain Shams University and Regional Center for Food and Feed (RCFF), Agricultural Research Center (ARC).

\section{Sprouting methods and experimental design}

Hays of wheat (L.E. 1750/ton), rice (L.E. 600/ton), Egyptian clover (L.E. 1750/ton) and Faba bean (L.E. 2000/ton) have been collected from a private farms located in Kaliobeya Governorate (2015). All hays were sun dried and chopped (2 $4 \mathrm{~cm})$. Then soaked in tap water or saline water ( $\mathrm{NaCl} 2000 \mathrm{ppm})$ over night and sterilized for 10 min in boiling water before used according to Mohammadi and Abdallah (2007). Grains of barley (Hordeum vulagre) used in this work. (L.E $4500 /$ ton) were obtained from the Local market (2015).

\section{Sprout production method}

Production method for barley grains etiolated sprouts was bag method as described by Cairney (1997) using hays of faba bean, Egyptian clover, rice and wheat as sprouting media. Grains of the barley were cleaned, washed and soaked in tap water or salted water ( $\mathrm{NaCl} 2000 \mathrm{ppm})$ for $12 \mathrm{hr}$. To allow for initial germination before mixed with hays media. Seeding density was used through 24 treatments [ 3 density $\times 2$ soaking solution as tap water and salted water ( $\mathrm{NaCl} 2000$ ppm) x 4 growing media as (rice, wheat, faba bean and Egyptian clover hays)]

Three densities of barely grains [10\%, $20 \%$ and $30 \% \mathrm{w} / \mathrm{w}$ ] were mixed with hays medium in the cloth bags each in 3 replicates. The bags with etiolated sprouts in the growing media were placed in germination lab in dark for 4 days.

\section{Data recorded}

Growing media with etiolated barley sprouts were harvested 4 days after seeding for measuring expected dry weight of forage (fodder) and dry samples were used for chemical analysis. Mean forage dry yield per unit, volume of grains $(1.00 \mathrm{k}$ $\mathrm{g})$ and sprouting unit area $\left(\mathrm{m}^{2}\right)$ were calculated. 

nutritional and economical value of the product

\section{Chemical composition investigation}

Fodder (forage) samples with raw media samples ( 0.0 grains) were dried in oven at $60^{\circ} \mathrm{C}$ for 72 hr., and ground in laboratory Wiley mill to pass through a 40-mesh sieve. Proximate analysis crude protein, fat, ash and crud fiber contents of samples were determined according to AOAC. (2012a). Total carbohydrates were determined by subtracting. Energy value was calculated using the Atwater factor method $[(9 \times$ fat $)+(4 \times$ carbohydrate $)$ + (4x protein)] as described by Eneche (1991); Chinma and Igyor (2007) and Nwabueze (2007).

Fiber fractions, NDF (Neutral Detergent Fiber), ADF (Acid Detergent Fiber) and ADL (Acid Detergent Lignin) were determined according to Van Soest and Robertson (1985) and AOAC (2012b).

For in vitro digestibility, modified method of Tilley and Terry (1963) and Brzezinski (1985) were used. Relative feed value (RFV) was calculated by estimating the digestibility of the forage dry matter (DDM) and how much the animal can eat (Dry Matter Intake DMI as a \% of Body weight) based on its "filling" capacity. Following the equation: $\mathrm{RFV}=\mathrm{DDM} \times \mathrm{DMI} \div 1.29$ according to Collins (1988). For etiolated sprout feed cost evaluation, the estimated cost of fodder dry matter (DM), total digestible nutrient (TDN) and protein in L.E. per ton for all treatment was calculated using the following equation: $\left\{T D N=D E / 4,409^{*} 100\right\}$ according to Blaxter (1966).

While $\left\{\mathrm{DE}=\mathrm{GE}{ }^{*} 0.76\right.$ \}according to N.R.C. (1988) and $\left\{\mathrm{GE}=\left(\mathrm{CHO}^{*} 4.15\right)+\left(\mathrm{EE}^{*} 9.4\right)+\right.$ $\left.\left(\mathrm{CP}^{\star} 5.65\right)\right\}$ while $\mathrm{CHO}=$ carbohydrate, $\mathrm{EE}=$ fats and $\mathrm{CP}=$ crude protein. $\{\mathrm{DMI}(\mathrm{BW} \%)=120 / \mathrm{NDF}$ $(\mathrm{DM} \%)\} .\{\mathrm{DDM}(\%)=88.9-\mathrm{ADF} \% \times 0.779\} .\{\mathrm{RFV}$ $=(\mathrm{DDM}) \times(\mathrm{DMI}) / 1.29\}$ according to (Collins 1988, Schroeder 2013 and Uttam et al 2010). Etiolated barely sprout system coast was estimated using base unit production area $(6 \mathrm{~m}$ length $\times 5 \mathrm{~m}$ width $\times 3 \mathrm{~m}$ height) for each production cycle (4 days= about 81 cycle per year), and each unite material calculated cost was about 415 L.E per cycle including labors enough for 10 years. However, these cycle coast are not including the grains and hays growing media.

The final production was compared with the prices of some of the fodder such as alfalfa; corn Silage, Hydroponic Barely, materials found in the Local market (2017), and Sprouted green barley with $100 \%$ seeding density on rice straw [estimated cost by Deraz, Hayam, 2015].

\section{Statistical analysis}

Data were statistically analyzed by analysis of variance using completely randomized design and least significant difference test (L.S.D.) at 0.05 levels according to the method described by Snedecor and Cochran (1980).

\section{RESULTS AND DISCUSSION}

Effect of seeding density grown in hays media using saline water on barley etiolated sprouts fodder yield

Data in Table (1) showed that the highest $(\mathrm{P}<0.05)$ fodder dry yield per unit area $(69.08 \mathrm{~kg} / \mathrm{m} 2)$ was obtained with using $30 \%$ seeding density grown in wheat hay medium with saline water for sprouting. Moreover, the dry fodder yield $(\mathrm{kg} / \mathrm{m} 2)$ increased with increasing seeding density in all growing hays media. Similar results was obtained by Deraz, Hayam, et al (2015), using wheat hays as a growing medium for green barely sprout fodder production.

On the other hand using $10 \%$ seeding density grown in rice hay medium recorded the highest $(P<0.05)$ fodder dry weight per unit volume of seeds $(9.1 \mathrm{~kg} / \mathrm{kg}$ grains) in both tap and saline ( $\mathrm{NaCl}$ 2000ppm) water [Table 1].

Opposite results were obtained by using 30\% seeding density grown in faba bean hays medium in both tap and saline water on fodder yield per unit volume of seeds ( $\mathrm{kg} / \mathrm{kg}$ grains).

Effect of barley seeding density, grown in hays media using saline water on the proximate analysis of 4 days old barley etiolated sprout fodder.

Data in Table (2) showed that fiber and ash contents were increased with decreasing seeding density. The increment of protein of barely etiolated sprout dry media fodder using tap water or saline water may be due to the higher protein content of the barely etiolated sprout grow in hays media for fodder production, because the protein content In barley grain etiolated sprouts with hays Increase with Increased the seeding density. These data agree with these obtained by Ibrahim et al (2001); Abdallah et al (2014) and Deraz, Hayam, et al (2015). 
Table 1. Effect of seeding density grown in hays media, using saline water ( $\mathrm{NaCl} 2000 \mathrm{ppm})$ on barley etiolated sprouts fodder dry yield $\left(\mathrm{kg} / \mathrm{kg}\right.$ seed) and $\left(\mathrm{kg} / \mathrm{m}^{2}\right)$ (combined data of two experiments)

\begin{tabular}{|c|c|c|c|c|c|c|c|}
\hline \multicolumn{2}{|c|}{ Characters } & \multirow{2}{*}{\multicolumn{3}{|c|}{$\begin{array}{c}\text { Forage }(\mathbf{k g} / \mathbf{k g} \text { seed) } \\
\text { Soaking water }\end{array}$}} & \multirow{2}{*}{\multicolumn{3}{|c|}{$\begin{array}{l}\text { Forage }\left(\mathrm{kg} / \mathrm{m}^{2}\right) \\
\text { Soaking water }\end{array}$}} \\
\hline \multirow[b]{2}{*}{ Growing hay media } & \multirow[b]{2}{*}{$\begin{array}{l}\text { Seeding } \\
\text { density }\end{array}$} & & & & & & \\
\hline & & $\begin{array}{c}\text { Tap } \\
\text { water }\end{array}$ & $\begin{array}{c}\text { Saline } \\
\text { water(NaCl } \\
\text { 2000ppm) }\end{array}$ & Mean & $\begin{array}{c}\text { Tap } \\
\text { water }\end{array}$ & $\begin{array}{c}\text { Saline wa- } \\
\text { ter(NaCl } \\
2000 p p m)\end{array}$ & Mean \\
\hline \multirow{4}{*}{ Rice } & $10 \%$ & $9.10 a$ & $9.10 \mathrm{a}$ & $9.10 \mathrm{a}$ & $48.43 r$ & $48.57 r$ & $48.50 \mathrm{j}$ \\
\hline & $20 \%$ & $4.82 \mathrm{i}$ & $4.94 h$ & $4.88 \mathrm{e}$ & $51.47 q$ & $52.77 p$ & $52.12 i$ \\
\hline & $30 \%$ & $3.51 n$ & $3.53 n$ & $3.52 \mathrm{i}$ & 56.261 & 56.531 & $56.37 f$ \\
\hline & mean & $5.81 a$ & $5.85 a$ & $5.83 \mathrm{~A}$ & $52.05 c$ & $52.62 c$ & 52.34D \\
\hline \multirow{4}{*}{ Wheat } & $10 \%$ & $8.81 b$ & $8.73 c$ & $8.77 b$ & $58.75 j$ & $58.24 \mathrm{k}$ & $58.50 \mathrm{e}$ \\
\hline & $20 \%$ & $4.75 j$ & $4.84 i$ & $4.79 f$ & $63.44 \mathrm{~g}$ & $64.58 \mathrm{e}$ & $64.01 \mathrm{c}$ \\
\hline & $30 \%$ & 3.420 & 3.450 & 3.43j & $68.55 \mathrm{~b}$ & $69.08 \mathrm{a}$ & $68.81 \mathrm{a}$ \\
\hline & mean & $5.66 a$ & $5.67 a$ & 5.66B & $63.58 \mathrm{a}$ & $63.97 a$ & 63.77A \\
\hline \multirow{4}{*}{ Faba bean } & $10 \%$ & $8.00 \mathrm{~g}$ & $8.05 f$ & $8.03 d$ & 53.380 & 53.730 & $53.55 \mathrm{~h}$ \\
\hline & $20 \%$ & $4.39 \mathrm{~m}$ & $4.40 \mathrm{~m}$ & 4.40h & $58.60 \mathrm{jk}$ & $58.83 \mathrm{j}$ & $58.71 e$ \\
\hline & $30 \%$ & $3.18 q$ & $3.18 q$ & $3.18 \mathrm{I}$ & $63.88 f$ & $63.73 \mathrm{fg}$ & $63.81 \mathrm{c}$ \\
\hline & mean & $5.19 a$ & $5.21 a$ & 5.20D & $58.62 b$ & $58.76 b$ & 58.69C \\
\hline \multirow{4}{*}{ Egyptian clover } & $10 \%$ & $8.26 \mathrm{e}$ & $8.31 d$ & $8.29 c$ & $54.99 n$ & $55.48 m$ & $55.23 \mathrm{~g}$ \\
\hline & $20 \%$ & 4.461 & $4.52 \mathrm{k}$ & $4.49 \mathrm{~g}$ & $59.57 i$ & $60.33 h$ & $59.95 d$ \\
\hline & $30 \%$ & $3.29 p$ & $3.25 p$ & $3.27 \mathrm{k}$ & $65.91 \mathrm{c}$ & $65.23 d$ & $65.57 b$ \\
\hline & mean & $5.33 a$ & $5.36 a$ & $5.35 \mathrm{C}$ & $60.15 a b$ & $60.35 a b$ & 60.25B \\
\hline \multirow{4}{*}{$\begin{array}{l}\text { Seeding density } \\
\text { mean }\end{array}$} & $10 \%$ & $8.54 a$ & $8.55 a$ & $8.54 \mathrm{~A}$ & $53.94 c$ & $54.00 c$ & 53.97C \\
\hline & $20 \%$ & $4.60 \mathrm{~b}$ & $4.67 \mathrm{~b}$ & 4.64B & $58.27 \mathrm{~b}$ & $59.13 b$ & 58.70B \\
\hline & $30 \%$ & $3.35 c$ & $3.35 c$ & $3.35 \mathrm{C}$ & $63.65 a$ & $63.64 \mathrm{a}$ & 63.64A \\
\hline & Mean & $5.50 \mathrm{~B}$ & $5.52 \mathrm{~A}$ & 5.51 & $58.60 \mathrm{~B}$ & $58.92 A$ & 58.76 \\
\hline \multicolumn{8}{|c|}{ L.S.D (0.05) } \\
\hline \multirow{3}{*}{\multicolumn{2}{|c|}{$\begin{array}{l}\text { Growing media (GM) } \\
\text { Soaking water (SW) } \\
\text { Seeding density (SD) }\end{array}$}} & \multicolumn{3}{|c|}{0.018} & \multicolumn{3}{|c|}{0.171} \\
\hline & & \multicolumn{3}{|c|}{0.012} & \multicolumn{3}{|c|}{0.121} \\
\hline & Seeding density (SD) & \multicolumn{3}{|c|}{0.015} & \multicolumn{3}{|c|}{0.148} \\
\hline \multicolumn{2}{|c|}{ GM $x$ SW } & \multicolumn{3}{|c|}{ N.S } & \multicolumn{3}{|c|}{3.996} \\
\hline \multicolumn{2}{|l|}{ GM $\times$ SD } & \multicolumn{3}{|c|}{0.045} & \multicolumn{3}{|c|}{0.489} \\
\hline \multirow{2}{*}{\multicolumn{2}{|c|}{ SW x SD }} & \multicolumn{3}{|c|}{0.237} & \multicolumn{3}{|c|}{3.555} \\
\hline & GM $\times$ SW $x$ SD & \multicolumn{3}{|c|}{0.044} & & 0.419 & \\
\hline
\end{tabular}

Small letters $(a, b, c \ldots)$ in the same column differ significantly between treatments at $(P<0.05)$.

N.S no significantly.

Data in Table (2) showed also that content of energy was increased with increasing barely seeding density. Data was more pronounced with using Egyptian clover hay as growing medium in barley etiolated sprout fodder experiment than others media using tap water or saline water. The higher energy increment using 30\% seeding density was about $74 \%$ than raw Egyptian clover ( $0 \%$ seed) in both tap water and saline water fodder.
Effect of barley seeding density, grown in hays media using saline water on fodder fiber fraction.

Data in Tables (3) cleared that percentage of NDF, ADF, ADL, cellulose and lignin were decreased with increasing seeding density of barley from $10 \%$ to $30 \%$ seed mixture with hays media using tap water or saline water for sprouting. Data was more pronounced with Egyptian clover hays medium as compared with other media by using tap water and saline water especially at lower seed 

nutritional and economical value of the product 

nutritional and economical value of the product

density (10\%). The lowest improved in NDF, ADF, $A D L$, cellulose and lignin were noticed at $10 \%$ seed density when barely grains grown in mixture with rice hays medium using tap water or saline water. Concerning hemicellulose \% data showed improvement in wheat hays media. While hemicellulose \% was increased in rice hays medium with increasing barley seed density. Similar results were obtained by Deraz, Hayam, et al (2015) on the fiber fraction of rice or wheat straw medium. However, these changes in fiber fraction in this study may be attributed to the degradation of rice, wheat, Egyptian clover and faba bean hays including enzymes catalyze the breakdown of the polysaccharide to the compared monosaccharide and disaccharide. Increasing degradation with Egyptian clover hays medium compared with other media may be explained by increasing the present of enzymes in etiolated barley sprouts and the present of saprophytic bacteria in Egyptian clover medium which may play a role in degradation as reported before by Mohammadi, Thanaa and Abdallah (2007). Therefore, the raw hays fiber fractions were improved when used as growing media for barley sprouts production as etiolated fodder. Similar results were obtained by Abdallah et al (2014) and Deraz, Hayam, et al (2015) in the sprout production as green fodder.

Effect of barley seeding density grown in hays media using saline water on In-vitro dry matter digestibility of etiolated sprout fodder

Data in Table (4) showed that, the highest increase in In- Vitro dry matter digestibility (INVDMD) after 4 days of barley seeding was noticed with the highest grain density (30\%). The data was more pronounced with faba bean hay dry medium (fodder). The lowest IN-VDMD was obtained with rice hay dry medium (fodder).

This increment in IN-VDMD with higher grain density may be due to the increment of nutrients and/or the dry etiolated sprout residues in the growing media. These results are agreement with these obtained by Deraz, Hayam, (2015) in green sprout production study.

Also, the increment in IN-VDMD with faba bean hays followed by Egyptian clover hays dry medium (fodder) may also related to its higher content of nutrients than rice and wheat hays medium.

\section{Economics of barley etiolated sprouts fodder}

\section{A- Relative feed value (RFV) of barley etiolated sprout fodder:}

Data of Table (5) showed that the DMl estimated percentage was increased with increasing barley seed density for both barley grown using tap water and saline water in mixture with all media hays.

However, the DMI of higher barley seeding density with Egyptian clover and faba bean hays media was almost equal to corn silage but both were less than hydroponic barley green sprouts. This is attributed to an increase in fiber content of etiolated sprouted barley grains grown with hays media compared to hydroponic barley green sprouts. Dry matter intake was also reduced due to higher water contents of sprouted seeds and corn silage, which make the feed bulky.

These data agree with those obtained by Fazaeli et al (2012); Hillier and Perry, (1969) and Myers, (1974). Also, Fayed (2001) found that barley sprouts with rice straw decreased feed intake in lambs. In contrary to this Eshtayeh (2004) in cows observed non-significant effect of sprouted grains on DMI. Data in Table (5) showed that the DDM estimated percentage was increased with increasing seed density for both barley seed grown in mixture rice, wheat, Egyptian clover and faba bean hays media. However, the DDM of higher barley grain density was close to corn silage DDM estimated \% but was less as compared with alfalfa and hydroponic barley green sprouts feedstuffs. The increasing DDM by increasing sprouted seeds density may be due to the presence of bioactive catalysts, which increases digestion, and absorption of nutrients. Ibrahim (2001) and Fayed (2011) observed an increase in nutrients digestibility by addition of sprouted grains in the diet of animals. Relative feed value index has been very useful for livestock producers and feed stuffs farmers to compare the quality of hays and silages. Data in Table (5) showed RFV index was increased with increasing barley-seeding density. Data was more pronounced using faba bean hays medium. Moreover, $30 \%$ seeding density grown in mixture with faba bean hays using saline water recorded the higher RFV index close to RFV index of corn silage (Table 5). 
Table 4. Effect of barley seeding density grown in hays media using saline water ( $\mathrm{NaCl} 2000 \mathrm{ppm})$ on the In- Vitro dry matter digestibility (IN-VDMD) of etiolated sprout fodder (dry growing media)

\begin{tabular}{|c|c|c|c|c|}
\hline \multirow{2}{*}{ Medium } & \multirow{2}{*}{ Seeding density $\%$} & \multicolumn{2}{|c|}{ Soaking water } & \multirow[b]{2}{*}{ Mean } \\
\hline & & Top & Saline(NaCl2000ppm) & \\
\hline \multirow{4}{*}{ Rice hay } & $\% 0$ & 37.2 & 38.64 & 37.92 \\
\hline & $\% 10$ & 39.57 & 40.27 & 39.92 \\
\hline & $\% 20$ & 43.56 & 45.80 & 44.68 \\
\hline & $\% 30$ & 51.97 & 53.93 & 52.95 \\
\hline \multicolumn{2}{|c|}{ Mean } & 43.08 & 44.66 & 43.87 \\
\hline \multirow{4}{*}{ Wheat hay } & $\% 0$ & 37.05 & 40.90 & 38.98 \\
\hline & $\% 10$ & 56.46 & 47.14 & 51.80 \\
\hline & $\% 20$ & 64.91 & 58.54 & 61.73 \\
\hline & $\% 30$ & 68.34 & 71.17 & 69.76 \\
\hline \multicolumn{2}{|c|}{ Mean } & 56.69 & 54.44 & 55.57 \\
\hline \multirow{4}{*}{ Egyptian clover hay } & $\% 0$ & 42.81 & 48.76 & 45.79 \\
\hline & $\% 10$ & 57.77 & 55.44 & 56.61 \\
\hline & $\% 20$ & 63.11 & 62.23 & 62.67 \\
\hline & $\% 30$ & 70.91 & 67.14 & 69.03 \\
\hline \multicolumn{2}{|c|}{ Mean } & 58.65 & 58.39 & 58.53 \\
\hline \multirow{4}{*}{ Faba bean hay } & $\% 0$ & 54.96 & 52.38 & 53.67 \\
\hline & $\% 10$ & 60.33 & 69.25 & 64.79 \\
\hline & $\% 20$ & 68.41 & 72.43 & 70.42 \\
\hline & $\% 30$ & 73.88 & 75.65 & 74.77 \\
\hline \multicolumn{2}{|c|}{ Mean } & 64.40 & 67.43 & 65.91 \\
\hline \multirow{4}{*}{$\begin{array}{l}\text { Seeding density } \\
\text { mean }\end{array}$} & $\% 0$ & 43.01 & 45.17 & 44.09 \\
\hline & $\% 10$ & 53.53 & 53.03 & 53.28 \\
\hline & $\% 20$ & 60.00 & 59.75 & 59.88 \\
\hline & $\% 30$ & 66.28 & 66.97 & 66.63 \\
\hline \multicolumn{2}{|c|}{ Mean } & 55.70 & 56.23 & 55.97 \\
\hline
\end{tabular}

\section{B- Barley etiolated sprout feed cost evaluation:}

Prices of feedstuff must be converted to a dry matter (DM) basis. To determine the cost of a nutrient, the dry matter feed cost divided by the percent nutrient in the feed. Data in Table (5) comparing estimated cost (L.E/Ton) of dry matter (DM), crude protein (CP) and total digestible nutrients (TDN) of barley etiolated sprouts grown in mixture with rice, wheat, faba bean and Egyptian clover hays at different seeding density as compared with commercial feed stuff (Corn Silage, Alfalfa, hydroponic using barley green sprouts and sprouted green barley on rice straw).

The cost per ton DM was increased parallel to increasing barley seeding density. Compared with corn silage, sprouting barley grain at all seeding density with rice hays under conditions of tap water and saline water producing etiolated barley fodder with DM, TDN and CP at a cost less to corn silage and green hydroponic barley per ton. Also provides
DM at a less cost to alfalfa and TDN at a more cost to alfalfa per ton (Table 5).

However, concerning to the increment and decrement relative cost (L.E/ton) percentage (Table 6), all etiolated barley sprouts grown in mixture with rice, wheat, Egyptian clover and faba bean hays at all seeding density under sprouting of tap water or saline water were most economical sources of DM, TDN and CP compared with hydroponic green barley sprout fodder. In comparing with corn silage only etiolated barley sprouts grown in mixture with rice hay medium at all seeding density were most economical sources of DM, TDN and CP. Regarding to relative cost percent compared to alfalfa only barley etiolated sprouts grown with rice hays were economical source of DM and TDN with approximately equal economic of CP. While barley etiolated sprouts grown with wheat hays were economical source of DM and TDN with no economic of CP (Table 6). 

nutritional and economical value of the product

Table 5. Relative feed value (RFV), dry matter intake (DMI), digestibility dry matter (DDM) and estimated cost (L.E/Ton) of Dry Matter (DM), crude Protein (CP) and Total Digestible Nutrients (TDN) of etiolated barely sprouts grown in mixture with rice, wheat, faba bean and Egyptian clover hays at different seeding density as compared with commercial feedstuff

\begin{tabular}{|c|c|c|c|c|c|c|c|}
\hline \multicolumn{2}{|l|}{ Feedstuff } & $\begin{array}{c}\text { DM } \\
\text { L.E./Ton }\end{array}$ & $\begin{array}{c}\text { TDN } \\
\text { L.E./Ton }\end{array}$ & $\begin{array}{c}\text { CP } \\
\text { L.E./Ton }\end{array}$ & $\begin{array}{c}\text { DMI } \\
\text { (\%BW) }\end{array}$ & $\begin{array}{c}\text { DDM } \\
\text { (\%BW) }\end{array}$ & $\begin{array}{c}\text { RFV } \\
\text { (\%BW) }\end{array}$ \\
\hline \multicolumn{2}{|l|}{ Corn Silage } & 3696 & 5686.15 & 46200 & 2.18 & 56.96 & 96.35 \\
\hline \multicolumn{2}{|l|}{ Alfalfa } & 3750 & 7211.54 & 22058.82 & 2.86 & 64.75 & 143.41 \\
\hline \multirow{2}{*}{\multicolumn{2}{|c|}{$\begin{array}{c}\text { Hydroponic Barely } \\
\text { Sprouted green barley on rice } \\
\text { straw } \\
\end{array}$}} & 6153.85 & 8424.16 & 35024.76 & 3.40 & 76.04 & 200.65 \\
\hline & & 3091.60 & 4384.63 & 36074.68 & 2.04 & 55.66 & 88.02 \\
\hline \multicolumn{8}{|c|}{ Tap water } \\
\hline \multirow{3}{*}{ Rice hay } & 10 & 1539.53 & 4261.08 & 28196.46 & 1.68 & 46.03 & 60.10 \\
\hline & 20 & 1948.30 & 5764.20 & 34422.27 & 1.78 & 47.52 & 65.37 \\
\hline & 30 & 2237.41 & 6083.23 & 31736.32 & 1.91 & 51.10 & 75.55 \\
\hline \multirow{3}{*}{ Wheat hay } & 10 & 2902.09 & 8397.26 & 68284.54 & 1.64 & 46.73 & 59.26 \\
\hline & 20 & 3206.11 & 9697.84 & 61302.24 & 1.69 & 49.44 & 64.65 \\
\hline & 30 & 3443.76 & 9434.95 & 56455.05 & 1.89 & 53.76 & 78.89 \\
\hline \multirow{3}{*}{ Egyptian clover hay } & 10 & 3127.79 & 9248.34 & 29507.44 & 1.84 & 44.73 & 63.92 \\
\hline & 20 & 3433.63 & 9804.77 & 31357.36 & 1.97 & 46.90 & 71.65 \\
\hline & 30 & 3617.32 & 9797.73 & 32153.98 & 2.02 & 48.70 & 76.12 \\
\hline \multirow{3}{*}{ Faba bean hay } & 10 & 3469.19 & 12642.82 & 40386.36 & 1.78 & 41.11 & 56.62 \\
\hline & 20 & 3711.96 & 12853.06 & 40656.77 & 1.96 & 45.07 & 68.32 \\
\hline & 30 & 3918.33 & 11195.23 & 41862.52 & 2.03 & 49.18 & 77.42 \\
\hline \multicolumn{8}{|c|}{ saline water ( $\mathrm{NaCl}$ 2000ppm) } \\
\hline \multirow{3}{*}{ Rice hay } & 10 & 1540.16 & 4280.59 & 29336.31 & 1.75 & 48.60 & 65.88 \\
\hline & 20 & 1896.37 & 5404.31 & 32923.15 & 1.75 & 48.88 & 66.21 \\
\hline & 30 & 2225.19 & 5897.67 & 28564.73 & 1.82 & 51.30 & 72.24 \\
\hline \multirow{3}{*}{ Wheat hay } & 10 & 2932.03 & 8818.13 & 67248.35 & 1.72 & 48.17 & 64.19 \\
\hline & 20 & 3143.48 & 9022.63 & 57784.61 & 1.77 & 51.43 & 70.66 \\
\hline & 30 & 3417.87 & 8779.53 & 52341.06 & 1.84 & 52.76 & 75.36 \\
\hline \multirow{3}{*}{ Egyptian clover hay } & 10 & 3110.05 & 9866.91 & 29818.32 & 1.89 & 46.80 & 68.41 \\
\hline & 20 & 3425.32 & 10433.51 & 30665.35 & 1.97 & 44.32 & 67.68 \\
\hline & 30 & 3651.11 & 10044.31 & 31286.27 & 2.02 & 48.80 & 76.30 \\
\hline \multirow{3}{*}{ Faba bean hay } & 10 & 3444.89 & 13834.91 & 41705.74 & 1.79 & 42.81 & 59.44 \\
\hline & 20 & 3688.90 & 12412.18 & 40987.76 & 1.89 & 47.47 & 69.65 \\
\hline & 30 & 3920.58 & 12026.31 & 38817.58 & 2.02 & 50.46 & 79.02 \\
\hline
\end{tabular}


Table 6. Increment and decrement relative cost (L.E/Ton) percentage of Dry Matter (DM), Total Digestible Nutrients (TDN) and Crude Protein (CP) of barely etiolated sprouts grown on rice, wheat, faba bean and Egyptian clover hays at different seeding density as compared with commercial feedstuff (Corn Silage) and (Alfalfa)

\begin{tabular}{|c|c|c|c|c|c|c|c|}
\hline \multicolumn{2}{|l|}{ Feedstuff } & $\begin{array}{c}\text { DM } \\
\% \\
\end{array}$ & $\begin{array}{c}\text { TDN } \\
\% \\
\end{array}$ & $\begin{array}{c}\text { CP } \\
\% \\
\end{array}$ & $\begin{array}{c}\text { DM } \\
\% \\
\end{array}$ & $\begin{array}{c}\text { TDN } \\
\% \\
\end{array}$ & $\begin{array}{l}\text { CP } \\
\% \\
\end{array}$ \\
\hline \multicolumn{2}{|l|}{ Corn Silage } & 100.00 & 100.00 & 100.00 & 98.56 & 78.85 & 209.44 \\
\hline \multicolumn{2}{|l|}{ Alfalfa } & 101.46 & 126.83 & 47.75 & 100.00 & 100.00 & 100.00 \\
\hline \multicolumn{2}{|c|}{ Hydroponic Barely } & 166.50 & 148.15 & 75.81 & 164.10 & 116.81 & 158.78 \\
\hline \multicolumn{2}{|c|}{ Sprouted green barley on rice straw } & 83.65 & 77.11 & 78.08 & 82.44 & 60.80 & 163.54 \\
\hline \multicolumn{8}{|c|}{ Tap water } \\
\hline \multirow{3}{*}{ Rice hay } & 10 & 41.65 & 74.94 & 61.03 & 41.05 & 59.09 & 127.82 \\
\hline & 20 & 52.71 & 101.37 & 74.51 & 51.95 & 79.93 & 156.05 \\
\hline & 30 & 60.54 & 106.98 & 68.69 & 59.66 & 84.35 & 143.87 \\
\hline \multirow{3}{*}{ Wheat hay } & 10 & 78.52 & 147.68 & 147.80 & 77.39 & 116.44 & 309.56 \\
\hline & 20 & 86.75 & 170.55 & 132.69 & 85.50 & 134.48 & 277.90 \\
\hline & 30 & 93.18 & 165.93 & 122.20 & 91.83 & 130.83 & 255.93 \\
\hline \multirow{3}{*}{ Egyptian clover hay } & 10 & 84.63 & 162.65 & 63.87 & 83.41 & 128.24 & 133.77 \\
\hline & 20 & 92.90 & 172.43 & 67.87 & 91.56 & 135.96 & 142.15 \\
\hline & 30 & 97.87 & 172.31 & 69.60 & 96.46 & 135.86 & 145.76 \\
\hline \multirow{3}{*}{ Faba bean hay } & 10 & 93.86 & 222.34 & 87.42 & 92.51 & 175.31 & 183.08 \\
\hline & 20 & 100.43 & 226.04 & 88.00 & 98.99 & 178.23 & 184.31 \\
\hline & 30 & 106.02 & 196.89 & 90.61 & 104.49 & 155.24 & 189.78 \\
\hline \multicolumn{8}{|c|}{ saline water ( $\mathrm{NaCl}$ 2000ppm) } \\
\hline \multirow{3}{*}{ Rice hay } & 10 & 41.67 & 75.28 & 63.50 & 41.07 & 59.36 & 132.99 \\
\hline & 20 & 51.31 & 95.04 & 71.26 & 50.57 & 74.94 & 149.25 \\
\hline & 30 & 60.21 & 103.72 & 61.83 & 59.34 & 81.78 & 129.49 \\
\hline \multirow{3}{*}{ Wheat hay } & 10 & 79.33 & 155.08 & 145.56 & 78.19 & 122.28 & 304.86 \\
\hline & 20 & 85.05 & 158.68 & 125.07 & 83.83 & 125.11 & 261.96 \\
\hline & 30 & 92.47 & 154.40 & 113.29 & 91.14 & 121.74 & 237.28 \\
\hline \multirow{3}{*}{ Egyptian clover hay } & 10 & 84.15 & 173.53 & 64.54 & 82.93 & 136.82 & 135.18 \\
\hline & 20 & 92.68 & 183.49 & 66.38 & 91.34 & 144.68 & 139.02 \\
\hline & 30 & 98.79 & 176.65 & 67.72 & 97.36 & 139.28 & 141.83 \\
\hline \multirow{3}{*}{ Faba bean hay } & 10 & 93.21 & 243.31 & 90.27 & 91.86 & 191.84 & 189.07 \\
\hline & 20 & 99.81 & 218.29 & 88.72 & 98.37 & 172.12 & 185.81 \\
\hline & 30 & 106.08 & 211.50 & 84.02 & 104.55 & 166.76 & 175.97 \\
\hline
\end{tabular}



nutritional and economical value of the product

Table 7. Increment and decrement relative cost (L.E/Ton) percentage of Dry Matter (DM), Total Digestible Nutrients (TDN) and Crude Protein (CP) of barely etiolated sprouts grown on rice, wheat, faba bean and Egyptian clover hays at different seeding density as compared with commercial feedstuff (Hydroponic Barely) and (sprouted green barley on rice straw)

\begin{tabular}{|c|c|c|c|c|c|c|c|}
\hline \multicolumn{2}{|l|}{ Feedstuff } & $\begin{array}{c}\text { DM } \\
\% \\
\end{array}$ & $\begin{array}{c}\text { TDN } \\
\% \\
\end{array}$ & $\begin{array}{l}\text { CP } \\
\% \\
\end{array}$ & $\begin{array}{c}\text { DM } \\
\% \\
\end{array}$ & $\begin{array}{c}\text { TDN } \\
\% \\
\end{array}$ & $\begin{array}{l}\text { CP } \\
\% \\
\end{array}$ \\
\hline \multicolumn{2}{|l|}{ Corn Silage } & 60.06 & 67.50 & 131.91 & 119.55 & 129.68 & 128.07 \\
\hline \multicolumn{2}{|c|}{ Alfalfa } & 60.94 & 85.61 & 62.98 & 121.30 & 164.47 & 61.15 \\
\hline \multicolumn{2}{|c|}{ Hydroponic Barely } & 100.00 & 100.00 & 100.00 & 199.05 & 192.13 & 97.09 \\
\hline \multicolumn{2}{|c|}{ Sprouted green barley on rice straw } & 50.24 & 52.05 & 103.00 & 100.00 & 100.00 & 100.00 \\
\hline \multicolumn{8}{|c|}{ Tap water } \\
\hline \multirow{3}{*}{ Rice hay } & 10 & 25.02 & 50.58 & 80.50 & 49.80 & 97.18 & 78.16 \\
\hline & 20 & 31.66 & 68.42 & 98.28 & 63.02 & 131.46 & 95.42 \\
\hline & 30 & 36.36 & 72.21 & 90.61 & 72.37 & 138.74 & 87.97 \\
\hline \multirow{3}{*}{ Wheat hay } & 10 & 47.16 & 99.68 & 194.96 & 93.87 & 191.52 & 189.29 \\
\hline & 20 & 52.10 & 115.12 & 175.03 & 103.70 & 221.18 & 169.93 \\
\hline & 30 & 55.96 & 112.00 & 161.19 & 111.39 & 215.18 & 156.49 \\
\hline \multirow{3}{*}{ Egyptian clover hay } & 10 & 50.83 & 109.78 & 84.25 & 101.17 & 210.93 & 81.80 \\
\hline & 20 & 55.80 & 116.39 & 89.53 & 111.06 & 223.62 & 86.92 \\
\hline & 30 & 58.78 & 116.31 & 91.80 & 117.00 & 223.46 & 89.13 \\
\hline \multirow{3}{*}{ Faba bean hay } & 10 & 56.37 & 150.08 & 115.31 & 112.21 & 288.34 & 111.95 \\
\hline & 20 & 60.32 & 152.57 & 116.08 & 120.07 & 293.14 & 112.70 \\
\hline & 30 & 63.67 & 132.89 & 119.52 & 126.74 & 255.33 & 116.04 \\
\hline \multicolumn{8}{|c|}{ Saline water ( $\mathrm{NaCl}$ 2000ppm) } \\
\hline \multirow{3}{*}{ Rice hay } & 10 & 25.03 & 50.81 & 83.76 & 49.82 & 97.63 & 81.32 \\
\hline & 20 & 30.82 & 64.15 & 94.00 & 61.34 & 123.26 & 91.26 \\
\hline & 30 & 36.16 & 70.01 & 81.56 & 71.98 & 134.51 & 79.18 \\
\hline \multirow{3}{*}{ Wheat hay } & 10 & 47.65 & 104.68 & 192.00 & 94.84 & 201.11 & 186.41 \\
\hline & 20 & 51.08 & 107.10 & 164.98 & 101.68 & 205.78 & 160.18 \\
\hline & 30 & 55.54 & 104.22 & 149.44 & 110.55 & 200.23 & 145.09 \\
\hline \multirow{3}{*}{ Egyptian clover hay } & 10 & 50.54 & 117.13 & 85.13 & 100.60 & 225.03 & 82.66 \\
\hline & 20 & 55.66 & 123.85 & 87.55 & 110.79 & 237.96 & 85.01 \\
\hline & 30 & 59.33 & 119.23 & 89.33 & 118.10 & 229.08 & 86.73 \\
\hline \multirow{3}{*}{ Faba bean hay } & 10 & 55.98 & 164.23 & 119.08 & 111.43 & 315.53 & 115.61 \\
\hline & 20 & 59.94 & 147.34 & 117.03 & 119.32 & 283.08 & 113.62 \\
\hline & 30 & 63.71 & 142.76 & 110.83 & 126.81 & 274.28 & 107.60 \\
\hline
\end{tabular}

However, cost is not the only factors to consider when evaluating feedstuffs. For example, $10 \%$ seeding density of barley etiolated sprouts grown in mixture with rice hays are very economical source of DM, TDN and CP. But the animal cannot eat enough of it to meet its nutritional re- quirements $(\mathrm{DMl}=1.87 \%$ to $1.97 \% \mathrm{BW})$, due to its lower relative feed value (RFV $=60$ to $65 \%$ BW) which considered low forage grades (fair $=<77$; grade $4=77-85$ and grade $3=87-102$ RFV) according to American Forage Grassland Councils (AFGC) quality standards. 
The $30 \%$ seeding density of barley etiolated sprouts grown with hays species medium recorded higher RFV close to grade 4 quality of AFGC standards and also its DMl equal for corn silage especially Egyptian clover and faba bean hays medium.

Also, DDM are close to $50 \%$ vs. 56.9 for corn silage. Therefore we can recommend $30 \%$ barley grain density $(290.78 \mathrm{~kg}$ grains with $969.27 \mathrm{~kg}$ of hays) grown in mixture with rice media or $30 \%$ barley grain density $(406.8 \mathrm{~kg}$ grains with $1356 \mathrm{~kg}$ of hays) grown in mixture with clover media for its economical of DM, TDN and CP than hydroponic green barley. In addition to etiolated sprout, fodder advantage on saving agriculture lands and power energy since it can grow in dark room on roofs in smaller area about 1:250 compared to corn silage and 1:500 compared to alfalfa. Also for its less water, consumption and higher quality nutrient sprout juice for animal. In addition, improving rice straw feeding quality for animal diets can be one of the alternative solutions to environmental problems.

Concerning to the increment and decrement relative cost (L.E/ton) percentage (Table 7) all etiolated barley sprouts grown on rice, wheat, Egyptian clover and faba bean hays at all seeding density under sprouting of tap water or saline water were most economical sources of DM, TDN and CP compared with Hydroponic Barely .In comparing with sprouted green barley on rice hays only etiolated barley grown on rice hays medium at all seeding density were most economical sources of DM, TDN and CP. Therefore we can recommend $30 \%$ barley grain density $(290.78 \mathrm{~kg}$ grains with $969.27 \mathrm{~kg}$ of hays) grown in mixture with rice media.

\section{REFERENCES}

Abdallah, M.M.F., Mahrous, N.M., Thanaa, F. Mohammdi and Mona, A. Abdel-Aziz, 2014. A New source of fresh green feed barley sprout grown on wheat or rice straw medium. J. of Environmental Sci.. (Cited from-Deraz Hayam et al 2015).

Al-Hashmi, M., 2008. Hydroponic green fodder World J. of Agric. Sci., 6(2), 171-177.

Al-Karaki, G.N. 2011. Utilization of treated wastewater for green forage production in a hydroponic system. Emirates J. of Food and Agric., 23, 80-94.
AOAC 2012a. Official methods of Analysis of AOAC International. $19^{\text {th }}$ ed. Dumes method. No. 968.06. Chapter 4, 25-26.

AOAC 2012b. Official methods of Analysis of AOAC International. $19^{\text {th }}$ ed. Dumes method. No.968.06 Chapter 4, 47-48.

Blaxter, K.L. 1966. The Energy Metabolism of Ruminants. $2^{\text {nd }}$ edition. Charles Thomas Publisher. Spring Field. Illinois, USA. III, 332 p.

Brzezinski, W. 1985. In vitro digestibility procedure in testing cultivars: In focus- The Tecator J. of Technology for Chemical Analysis. 21, 347-357.

Buston, C.D.E., Gonzalez, E.L., Aguilera, B.A. and Esptnoz, G.J.A. 2002. Forrajehi dropóni counaal ternativa para la supplement ación caprinaen el semidesierto Queretano XXXVIII Reunión Nacional de Investi gación Pecuaria. (Puebla, México). 383 p.

Cairney, E. 1997. The sprouters Handbook, Argyll Publishing Glendrauel, 2rd edition. Argy 11 PA 22 3E, Scotland. pp. 47-49.

Chinma, C.E. and Igyor, M.A. 2007. Micronutrients and anti-nutritional contents of selected tropical vegetables grown in South East, Nigeria. Nig. Food J., 25, 111-116.

Chung, T., Nwokolo, E.N. and Sim, J.S. 1989. Compositional and digestibility changes in sprouted barely and canola seeds. Plant Food for Human Nutrition, 39, 267-278.

Collins, M. 1988. Composition and fiber digestion in morphological components of alfalfa-timothy sward. Anim Feed Sci. Tech., 19, 135-143.

Deraz, Hayam. S.M. 2015a. Economics of Producing and Using Sprout Fodder as Untraditional Animal Feeds. Unpublished M.Sc. Thesis, Arid Land Agricultural Graduate Studies and Research Institute, Fac. of Agric., Ain Shams Univ., Cairo, Egypt, pp. 41-52.

Deraz, Hayam, S.M., El-Sebai, M.N., Thanaa, F. Mohammadi and Abdallah, M.M.F. 2015b. Economical and Nutritional Value of Forages Barley and Faba bean Sprout Grown on Wheat and Rice straw. J. Biol. Chem. Environ. Sci., 10(2), 183-201.

El-Deeba, Mona, M., El-Awady, N.M., Hegazi, M.M., Abdel-Azeem, A.F. and El-Bourdiny, M.M. 2009. Engineering, factors, affecting, hydroponics grass-fodder production. The $16^{\text {th }}$. Annual Conference of the Misr Society of Ag. Eng., 25 July 2009 Agricultural engineering and variables of the present epoch: pp. 16471666. 

nutritional and economical value of the product

El-Tahan, A.A.H., Abd El-Rahman, G.A., Sarhan, M.A. and Abo Ammo, F.F. 2003. Utilization of mushroom by-products for feeding ruminant. 2 . Utilization of mushroom by-products for feeding sheep. Egyptian J. of Nutrition and Feeds. 6 (Special Issue), 870-890.

Eneche, E.H. 1991. Biscuit-making potential of millet/pigeon pea flour blends. Plants Foods Human Nutr., 54, 21 - 27.

Eshtayeh, F.A.l. 2004. A new source of fresh green feed (Hydroponic barley) for Awass Sheep. M.Sc. in Environmental sciences, Fac. of Graduate studies, at An Najah National Uni., Nablus, Palestine pp. 19-26.

Fayed, Afaf, M. 2011. Comparative and feed evaluation of sprouted barley grains on rice straw versus Tamarix Mannifera on performance of growing barki lambs in Sinai. J. American Sci., 7(1), 954-961.

Fazaeli, H., Golmohammadi, H.A., Tabatabayee, S.N. and Asghari-Tabrizi, M. 2012. Productivity and nutritive value of barley green fodder yield in hydroponic system. J. Agric. Sci. Tech. 16(4), 531-539.

Helal, H.G. 2012. Sprouted barley grains on rice straw and acacia saligna and its effect on performance of growing barki lambs in Sinai. Proc. of the $5^{\text {th }}$ Scientific Conference of Animal Wealth Research in the Middle East and North Africa, Faculty of Agriculture, Cairo University, Giza, Egypt, 1-3 October 2012 ref.42, pp. 331346.

Hillier, R.J. and Perry, T.W. 1969.Effect of hydroponically produced oat grass on ration digestibility of cattle. J. of Animal Sci., 29, 783-785.

Ibrahim, Fathia, A., Hoda, M., El-Hosseiny and EI- Sayed, I.M. 2001. Effect of using sprouted barley by recycle process of agriculture residues on feeding value, rumen activity and some blood constituents of crossbred sheep. Egyptian J. Nutrition and Feeds, 4 (Special Issue), 265- 273.

Mason, V.C. and Owen, E. 1985. Urea versus ammonia for upgrading graminocesus material. In: Towards optimal feeding of agricultural byproducts of livestock in Africa. Proceeding of a workshop held at the University of Alexandria, October 1985. ILCA, Addis Ababa, Ethiopia. pp. 50-54.
Mohammadi, Thanaa. F. and Abdallah, M. M. F. 2007. Effect of four seed sprouts on rice straw and spent mushroom media of rice straw to be used green fodder. Egyptian. J. Nutrition and feeds, 10(2), 679-691.

Mukhopad, Yu, 1994. Cultivating green forage and vegetables in the Buryat Republic. Mezhdunarodnyi Sel' Skokhozyaistvennyi Zhurnal (6), 51-52.

Myers, J. 1974. Feeding livestock from the hydroponic garden. M.Sc. Thesis, Arizona State Univ., United states, pp. 29-42.

N.R.C, 1988. National Research Council. Nutrient requirements of dairy cattle. $15^{\text {th }}$ edition. National Academy Press, Washington, D.C. USA. pp. 71-77.

Nwabueze, T.U. 2007. Nitrogen solubility index and amino acid profile of extruded African breadfruit (T. Africana) blends. Nig. Food. J. 25, 35 - 35.

Rajendra, P., Seghal, J.P., Patnayak, B.C. and Beniwal, R.K. 1998. Utilization of artificially grown barley fodder by sheep. Indian J. Small Rumin. 4(2), 63-68.

Schroeder, E.A. 2013. Epigenetic silencing mediates mitochondria stress-induced longevity. Cell Metab, 17(6), 954-964.

Sneath, R. and Mclntosh, F. 2003. Review of hydroponic fodder production for beef cattle. Department of Primary Industries: Queensland Australia 84, $54 \mathrm{p}$.

Snedecor, G.W. and Cochran, W.G. 1980. Statistical methods. $7^{\text {th }}$ ed. lowa State Unv. Press. Ames. Lowa, U.S.A. 215, 37 p.

Tilley, J.M.H. and Terry, R.A. 1963. A two-stage technique for the in vitro digestion of forage crops. J. Brit. Grass Soc. 18, 104-111.

Tudor, G., Darcy, T., Smith, P. and Shall Cross, F. 2003. The intake and live weight change of drought master steers fed hydroponically grown, young sprouted barely fodder (Auto grass). Dept., of Agric. Western Australia Univ., (Cited from Fazaeli et al 2012).

Uttam, K., Ravindra, K., Patel, M., Sinha, A.P. 2010. Performance of crossbred pigs fed on Niger seed cake. Indian J. Anim. Sci., 80(10), 1034-1036.

Van Soest, P.J. and Robertson, J.B. 1985. Analysis of Forages and Fibrous Feeds. A Laboratory Manual for animal science 613, 202.p. Cornell University, Ithaca, New York, USA. 